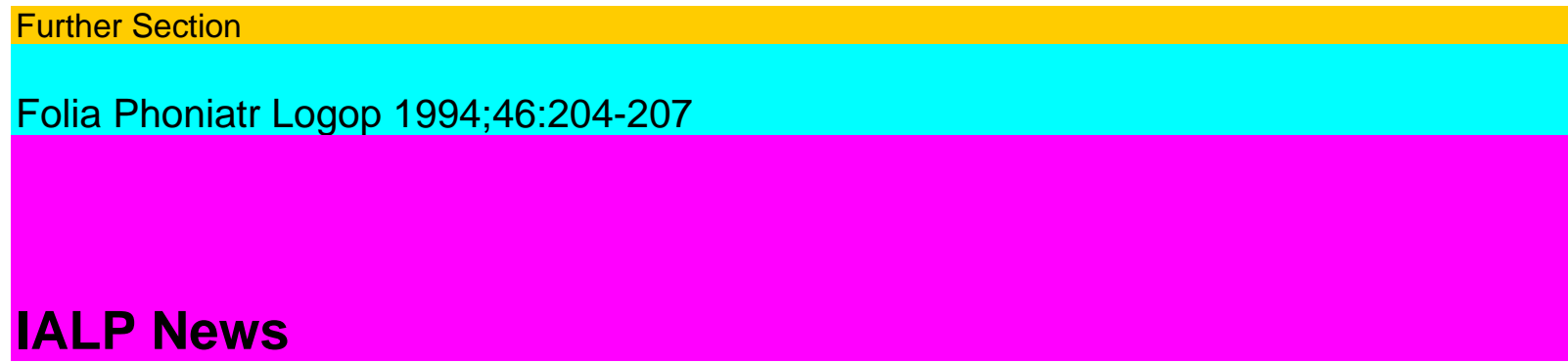

1ALr Informative and consultative status (category B) with N EWS UNESCO, UNICEF, WHO, ECOSOC and CIOMS

Folia Phoniatr 1994;46:204-207

Summer School:

Communication Disorders in Children

Date: Monday, July 11, to Friday, August 5, 1994.

Location: University of Manchester.

Aims:

To equip health and education professionals with the skills to recognise, assess and manage children who have communication disorders.

To enable course participants to transfer the above skills and/or to act as advisers to other health and education workers working with children who have communication disorders on with the carers of these children.

Target audience: Qualified health or education professionals from countries where services for children with communication disorders are not yet fully developed.

For further enquiries, please contact:

Julie Marshall/Jennifer Warner

Lecturers in Speech Pathology

Centre for Audiology

Education of the Deaf and Speech Pathology

University of Manchester

Oxford Road

Manchester M13 9PL (UK)

Tel. 0612753389 Fax 0612753519

Deutsche Gesellschaft für Phoniatrie und Pädaudiologie e.V.: Annelie-Frohn-Preis 1994

Für das Jahr 1994 wird erneut der Annelie-Frohn-Preis von der Deutschen Gesellschaft für Phoniatrie and Pädaudiologie und der Annelie-Frohn-Stiftung ausgeschrieben. Die Dotation beträgt DM 10 000,-. Der Preis wird für die beste wissenschaftliche Arbeit, die die Förderung hör- und/oder sprachgestörter Kinder zum Thema hat, vergeben.

Arbeiten sind bis zum 30. Juni 1994 einzureichen an das

Präsidium der

Deutschen Gesellschaft für Phoniatrie und Pädaudiologie

z. Hd. Prof. Dr. M. Gross

Hindenburgdamm 30

D-12200 Berlin

Award to Dr. Thomas Karger 
In November 1993, Dr. Thomas Karger, president of S. Karger Publishers, which publishes Folia Phonia-trica et Logopaedica, was awarded an honorary doctorate by the Faculty of Medicine of the University of Basel.

In their laudatory address the Faculty acknowledged his achievements as founder and publisher of a large number of internationally renowned journals covering a wide range of medical and scientific fields as well as his generous financial support of young medical scientists.

Recognition was also given to his successful organization of international symposia devoted to current interdisciplinary topics in biomedical research, which has enhanced the reputation of Basel and its university as centers of scientific achievement.

Already in 1972 Thomas Karger had received his first honorary doctorate from the University of Hamburg in recognition of his efforts on behalf of medical science.

The Editors of Folia Phoniatrica et Logopaedica take part in this award and join to congratulate him.

Symposium in Honor of Prof. Ernst Loebell

A symposium was held in honor of Prof. Loebell on the occasion of his retirement in Hannover on March 19, 1994. He founded the Phoniatrische und Pädaudiologische Klinik and a logopedic school in Hannover, chairing these institutions for 14 years. He has always concerned himself with the newest developments in his field, collaborating with neighboring specialities.

The symposium entitled 'Modern Aspects and Perspectives in Phoniatrics and Pediatric Audiology' covered the following topics:

Prof. M. Gross, Berlin, Präsident der Deutschen Gesellschaft für Phoniatrie und Pädaudiologie:

Gruss-wort; Prof. M. Heinemann, Mainz: Leben und Wirken von Prof. E. Loebell; Prof. T.

Hacki, Regensburg: The-rapiezentrierte Stimmdiagnostik; Dr. J. Hanson, Dessau:

Zentralorganische Sprachentwicklungsstörungen; Dr. W. Engelke, Göttingen: Bilder vom

Sprechen: Kombinierte Bild- und Signalverarbeitung in der Diagnostik von

Artikulationsstörungen; Prof. J.-E. Hausamen, Hannover: Differentialindikationen und funktionelle Gesichtspunkte bei der Zungenrekon-struktion; Dr. D. Lübben, Münster: Phoniatrie in der Praxis: Möglichkeiten und Perspektiven; Dr. H.-J. Radii, Bochum: Laryngitis gastrica; Prof. U. Eysholdt, Erlangen: Auswertung von Hochgeschwindigkeits-Videoaufnahmen der Stimmlippenschwingungen; Dr. P. Zorowka, Mainz: Untersuchungen zur Altersab-hängigkeit der transitorisch evozierten otoakustischen Emissionen; Prof. M. Gross, Berlin: Zentralregister für kindliche Hörstörungen; Prof. E. Kruse, Göttingen: Frühförderung hörbehinderter Kinder: Eine logopädi-sche Aufgabe? Prof. A. Lamprecht-Dinnesen, Münster: Phoniatrischpädaudiologische Aspekte bei der Vordiagnostik und der postoperativen Rehabilitation Cochleaimplantierter Kleinkinder. The text of the communications may be obtained from:

Dr. R. Schönweiler

Klinik für Phoniatrie und Pädaudiologie Medizinische Hochschule Hannover KonstantyGutschow-Strasse 8 D-30625 Hannover (Germany)

IALP Applied Audiology Committee

Prof. Herbert Oyer, chairman of the AAC, is proud to announce that his Proposal for the Training of Audiological Assistants has now been adopted by Dr. Suchitra Prasansuk, Director of the Otological Center at the ENT Department, Faculty of Medicine in Bangkok. She hopes by undertaking this training program to help many developing countries around Thailand. Dr. Pal Kapur, President of Hearing International and member of the AAC, has been instrumental in finalizing the arrangements with the Otological Center of Bangkok. This proposal has been published in IALP News 1993/No. 6. 
The Trained Audiological Assistants could function in a number of capacities in the field under appropriate supervision, where they are identifying those in need of medical help and are also rendering first echelon care and within institutions wherein they could provide assistance to the ENT doctors.

Prof. Oyer and his Committee continue to explore sites in other parts of the world for the placement of this training program and are open to any suggestion.

Sous Гégide du College français d'ORL et de chirurgie cervico-faciale: $8 \mathrm{e}$ cours de phonochirurgie

Lyon, 27 et 28 Janvier 1995

Cours organise par les Docteurs Marc Bouchayer et Guy Cornut. Ce cours portera sur les indications, techniques et résultats de la microchirurgie instrumentale des cordes vocales (laser excepté). Demonstrations opératoires télévisées, video, exposes théoriques, materiel. Droits d'inscriptions: médecins ORL et phoniatres, FF 2400; orthophonistes, FF 1000.

Nombre de participants: limité à 60 médecins et 10 orthophonistes.

En complement du cours, dimanche 29 Janvier (matin): Initiation aux techniques de stroboscopie video (travaux pratiques et interpretation des images). Nombre de participants limité à 30; droits d'inscription FF650.

Inscriptions et renseignements:

Secretariat du Docteur Cornut 90, rue Boileau F-69006 Lyon (France)

Fax (33) 78244824

205

Book Reviews · Buchbesprechungen · Livres nouveaux

A. Rodriguez-Gonzalez

Llenguatge de Signes Catalá

Barcelona, Generalitat, 1993

$44 \mathrm{pp}$.

ISBN 84-393-2729-3

Sign language is more and more introduced not only in large communities, but also in countries with minority idioms. This book was designed to be the first standard study for teaching sign language in Catalonia, a region in Spain, where people speak the Catalan language.

The text is coherent and systematic. Under the skilled direction of the coordinator, teachers of large experience (Boldu, Calafell, Cedilla y Mateu) have efficiently collaborated to produce this book.

It fulfils the needs of those teaching, because soon the Catalan Parliament will officially regognize the sign language.

G.H. Joachim, S. Frillwitz International Bibliography of Sign Language

Hamburg, Signum, 1993 ISBN 3-927731-33-1

Currently there is an increasing interest in sign language. A demonstration of this is this book that does not want to recommend the sign method for teaching the deaf child but represents a bibliography about it.

The bibliography lists 6,000 books and articles. Undoubtedly this volume is basic and indispensable for further studies of sign language.

J. Perelló

D. Crystal, R. Varley

Introduction to Language Pathology; ed. 3

London, Whurr, 1993 


\section{E 14.95}

(In USA Singular Publishing Group Inc. \$ 29.95)

This third edition of Introduction to Language Pathology illustrates clearly the many exciting developments that have taken place in the field of speech and language therapy over the past decade. Crystal and Varley bring this edition up to date by accounting for changes, not only in assessment and treatment approaches but also by considering important 'new atti-dudes [which] have emerged in the subject' (page v). This 'timely revision' benefits from the contribution of Crystal's co-author, Rosemary Varley, a speech and language therapist, who lends a much needed therapeutic dimension to many of the issues discussed - a feature lacking in previous editions. The result is a comprehensive introduction to the area of language pathology, enhanced by an appropriate balance of theoretical and clinical viewpoints.

New and changing attitudes to the profession have caused speech and language therapists to reexamine their role. The authors begin the first chapter by addressing this issue and discuss the many terminological confusions that abound when speech and language therapists attempt to describe who they are and what they do. The often devastating effects of a communication disability are also dealt with in this opening chapter and are illustrated by vignettes which give valuable insights into the experience of such disability. The chapter closes with a reference to the now fashionable holistic approach to the management of a communication disorder. The format of this initial chapter encompasses: '... both modes of knowing, juxtaposing ideas about terminology and theoretical frameworks, on the one hand, with personal anecdote and history on the other' (p. 16). Such a format is reflected throughout the book, successfully aiding integration of sometimes difficult material.

Models of language disability is the subject of the second chapter. Here, both behavioural and medical models are discussed, considering their strengths and limitations when applied to the investigation and remediation of communication disorders. Those models

\section{6}

\section{IALP News}

based on linguistic and a psychological dimension are also presented. This chapter therefore serves to provide the reader with a general view of language pathology by outlining the main scientific approaches to it.

Both the behavioural and medical perspectives are further dealt with within the notion of the 'Communications Chain'. This framework (which was a key feature of the previous editions) forms the basis of the central chapters of the book. The 'Communications Chain' model has grown over the years to accommodate greater understanding with regard to language processing. We are now a long way from the simple model of 'Production-Transmission-Reception' outlined in the first edition (1980); additional features include for example prelinguistic functions, motor programming, perception and message interpretation. Behavioural (chapter 3) and physical (chapter 4) aspects of communication are therefore discussed within this framework. Interpreting what goes on at each stage of the chain further provides the reader with a framework within which to classify and understand disability (chapter 5). For example, dementia or autism are discussed with regard to a breakdown at the prelinguistic stage of the chain while dysarthria illustrates breakdown at the motor execution stage etc. This approach for discussing the many aspects of normal and abnormal communication proves very effective. Such an integrative perspective is highly commendable in an introductory text, as student clinicans in particular tend to separate out various aspects of communication, thus failing to interpret the disability from a 
holistic and coherent viewpoint. Though the authors admit to the framework's limitations, it is clear that its strengths far outweigh its weaknesses.

The authors advocate having a strong theoretical foundation to the study of language pathology. Having provided just that in previous chapters Crystal and Varley in their final chapter outline important considerations in the management of communication disorders. They discuss the role of the speech and language therapist highlighting his/her role in prevention, in research and development of the subject and as an information giver. Advantages and disadvantages of different assessment approaches are discussed along with an overview of various models of intervention

(e.g. patient-, carer-, and context-centred). In so doing they emphasise the functionalist and holistic attitude to treatment and see the various models as essentially complementary. Introduction to Language Pathology is an excellent introductory text giving a comprehensive account of what is involved in communication and in communication disability. This edition profits greatly from the clinical perspective which helps to clarify and improve discussions of various issues related to language pathology. Because of the nature of their content, the chapters should perhaps be read consecutively. At the same time the book's comprehensive subject and author index render it useful for quick and easy reference. The text is easy to read, enhanced by numerous examples of anecdotes and excerpts of discourse of the various disorders under study. These features coupled with the tutorial activities at the end of each chapter serve to enrich the reader's understanding of this challenging subject.

This most recent edition of Introduction to Language Pathology remains essential reading for the student speech and language clinician. In addition it will continue to serve as an invaluable reference text for speech and language therapists and other related disciplines.

Irene P. Walsh

School of Clinical Speech and Language Studies,

Trinity College, Dublin

Monserrat Bonet

Manual de rehabilitación del sordo adulto

Barcelona, Masson, 1993

$160 \mathrm{pp}$.

ISBN 34-311-0660-3

We are accustomed to see a lot of literature on child deafness, but publications about deafness in old people are rare. Reading this book we realize how many things we can do to care for and improve the life of the old people.

207 